\title{
MUSCULAR INVOLVEMENT IN GIANT-CELL ARTERITIS
}

\author{
BY \\ R. W. ROSS RUSSELL \\ Department of the Regius Professor of Medicine, Radcliffe Infirmary, Oxford
}

Giant-cell arteritis is now known to occur not only in the cranial arteries, but in many large arteries throughout the body. In the case described below a severe generalized inflammation of the small muscular arteries followed a typical attack of temporal arteritis. It is suggested that a similar lesion may account for other cases of muscular weakness and wasting of obscure aetiology in elderly patients.

\section{Case Report}

An 80-year-old retired seaman was in his usual robust health until September, 1959, when he noticed a tender lump in the left temple, followed by a similar swelling on the other side. One week later he began to have intermittent attacks of pain in the temples and across the forehead, lasting for 2 to 3 hours at a time. Codeine tablets gave some relief at night, but the headaches were usually present again on waking. The scalp was tender and reddened. When the headaches were severe he sometimes noticed blurring of vision in the right eye (the left had been virtually blind from cataract for some years) and was unable to read for 2 to 3 hours. Between attacks the vision returned to normal.

In the past he had had a number of accidents, including a head injury in the first war which left him with a slight paresis of the left arm. There was no previous complaint of headache.

Examination.-There was hard bony swelling in the left temple. Both superficial temporal arteries were thickened and tortuous: pulsation was just detected on the right, but was absent on the left. In the right fundus the arteries were attenuated, but there were no haemorrhages, exudates, or optic atrophy. The visual acuity of the right eye was J2 and 6/9 with full visual field. The pupillary reaction to light was brisk and there were no other abnormalities in the cranial nerves. The left arm showed signs of a mild spastic paresis and the left plantar response was extensor, but the limbs were otherwise normal. There was a mild fever up to $100^{\circ} \mathrm{F}$.

Laboratory Tests.-There was a slight normocytic anaemia and a markedly raised erythrocyte sedimentation rate $(106 \mathrm{~mm} . / \mathrm{hr}$ Westergren$)$.
Treatment.-He was admitted to hospital under the care of Mr. J. Pennybacker and a small osteoma was removed from the left temple. An arterial biopsy of the left superficial temporal artery showed changes typical of giant-cell arteritis (Fig. 1).

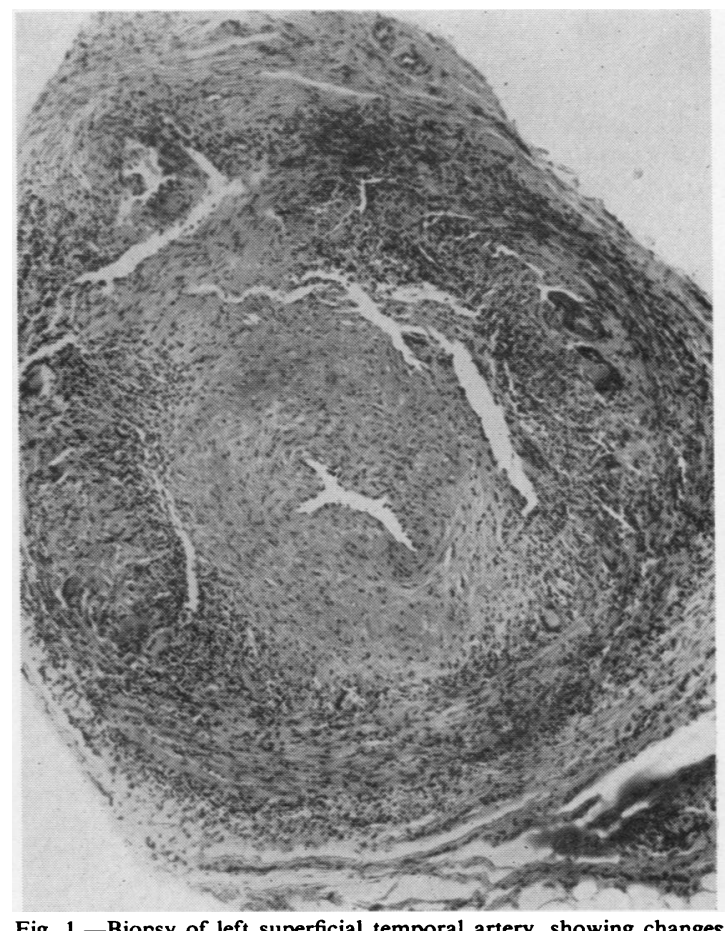

Fig. 1.-Biopsy of left superficial temporal artery, showing changes typical of giant-cell arteritis.

He was put on a maintenance dose of corticosteroids (cortisone $50 \mathrm{mg}$. three times a day with potassium supplement) and discharged from hospital.

Progress.-During the next year he was seen from time to time as an out-patient and he remained at work and free of all but occasional headaches. The erythrocyte sedimentation rate was $20-50 \mathrm{~mm}$./ hr, and the haemoglobin 70-80 per cent. Pulsation in the remaining temporal artery returned to normal. 
In August, 1960, he began to complain of aching in the arms and legs, backache, and swelling of the ankles. He felt generally unwell and had some return of headache. He was febrile $\left(101^{\circ} \mathrm{F}\right.$.) and erythrocyte sedimentation rate rose to $103 \mathrm{~mm}$. $/ \mathrm{hr}$. He lost muscle power rapidly and had to be re-admitted to hospital because he was unable to stand or to feed himself. He was unable even to sit up in bed because of muscle weakness which was maximal in the limb-girdle muscles. Power was virtually absent in deltoid, pectoral, and quadriceps muscles and was severely reduced in biceps, triceps, hamstrings, and glutei. The distal limb muscles were affected to a lesser degree. Muscle wasting was generalized and in proportion to weakness. There was only slight muscle tenderness and no fasciculation. The reflexes were preserved and there was no sensory loss apart from loss of vibration in the legs. He was in mild congestive heart failure and the blood pressure was $150 / 80 \mathrm{~mm}$. Hg.

Further Laboratory Investigations.-Intravenous injection of Tensilon (10 mg.) had no influence on the muscle weakness.

Hb 72 per cent. (10.7 g.); mean corpuscular haemoglobin concentration 30 per cent.; reticulocytes 1.6 per cent.; red cells showed anisocytosis and hypochromia; white blood cells $12,800 \mathrm{c} . \mathrm{mm}$. (neutrophil leucocytosis); no L.E. cells.

Bone marrow was cellular and red cell maturation normal.

Blood urea $41 \mathrm{mg} . / 100 \mathrm{ml}$.

Plasma sodium $137 \mathrm{mEq} / \mathrm{l}$, potassium $4.2 \mathrm{mEq} / \mathrm{l}$, chloride $95 \mathrm{mEq} / \mathrm{l}$., bicarbonate $33 \mathrm{mEq} / \mathrm{l}$.

Plasma proteins $5.6 \mathrm{~g} . / 100 \mathrm{ml}$, albumin $1.8 \mathrm{~g} . / 100 \mathrm{ml}$. Electrophoresis showed increased gamma globulin.

Rose's differential agglutination test was positive to a titre of 64 .

Latex test positive.

Serum $\mathrm{B}_{12} 103 \mu \mathrm{g} . / \mathrm{ml}$.

Urinary creatinine $820 \mathrm{mg} .12 \mathrm{hrs}$, creatine $590 \mathrm{mg}$. 24 hrs.

Wassermann reaction negative.

$X$-ray of shoulders showed minor osteo-arthritic changes; $x$-ray of chest showed cardiac enlargement and aneurysmal dilatation of the aorta with sclerosis.

Electromyography of the right deltoid, biceps, and triceps (Dr. G. Rushworth) showed no spontaneous activity at rest. Voluntary effort evoked moderately complex pattern of action potentials up to 3,000 microvolts in amplitude (triceps not over 1,000 microvolts), and of average duration $10 \mathrm{msec}$. Many were highly polyphasic.

Progress.-Corticosteroid injections were increased (prednisolone $90 \mathrm{mg}$./day) with iron and vitamins by mouth. Digoxin, hydroflumethiazide, and Nilevar, which he had been given as an out-patient, were continued.

He made a rapid recovery over one month and the erythrocyte sedimentation rate declined to $32 \mathrm{~mm}$. $/ \mathrm{hr}$. Muscle power improved remarkably, but wasting was still obvious when he was discharged after 5 weeks.

Death.-Improvement continued at home, but 2 months later he developed broncho-pneumonia, and in spite of tetracycline and increased doses of corticosteroids, hes. rapidly deteriorated and died. Permission for autopsy was refused.

\section{Microscopic Examinations}

(1) Temporal Artery Biopsy.-The specimen, taken 15 months before death, shows changes typical of giant 0 cell arteritis (Fig. 1). The adventitia and media arês heavily infiltrated with lymphocytes and fibroblasts. There are areas in the media where the muscle fibres have? disappeared and have been replaced by granulation $-\vec{\omega}$ tissue, including giant cells. The intima is greatlyo thickened and contains a number of epithelioid cells together with fibroblasts and smooth muscle cells. The lumen is greatly reduced but contains no thrombus.

\section{(2) Muscle Biopsies}

(a) Deltoid Muscle.--The specimen, taken 3 months before death, contains a medium-sized muscular artery showing marked inflammatory changes (Fig. 2).

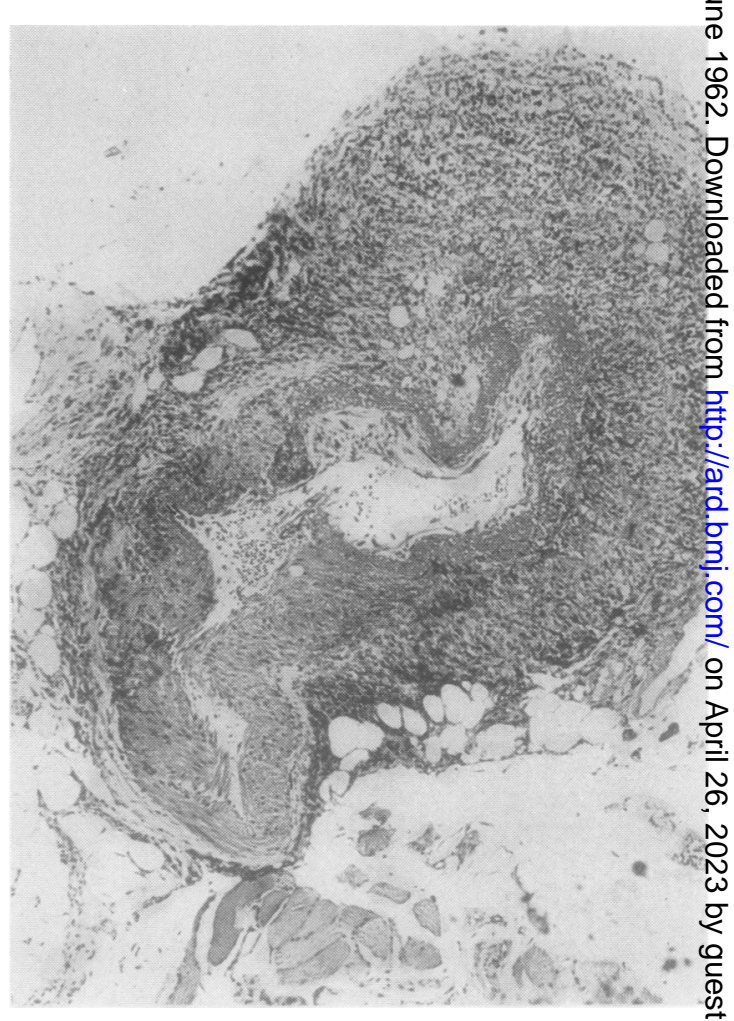

Fig. 2.-Biopsy of deltoid muscle, showing inflammatory arterial changes.

The adventitia is infiltrated with great numbers of lymphocytes and fibroblasts and smaller numbers of plasma cells and polymorphs. Part of the muscular coat has been destroyed and all that remains is a band of 
eosinophilic fibrinoid material. A very few giant cells are present in this area. The intima is thickened and contains a few fibroblasts and lymphocytes. There is no thrombus in the lumen. A neighbouring vein is entirely normal. The muscle bundles in the vicinity of the inflamed artery show interstitial lymphocytic infiltration. There is much variation in the calibre of muscle fibres. Subsarcolemmal nuclei are increased in number. Occasional muscle fibres are necrotic and are undergoing phagocytosis.

In a preparation stained intravitally with methylene blue, the distal nerve fibres show some increase in tortuosity and in branching, and the motor end-plates show slight degenerative changes.

(b) Quadriceps Muscle.-In this specimen, taken 3 months before death, the muscle fibres show more interstitial cellular infiltration than in the deltoid muscle. Some of the bundles have necrosed and are replaced by granulation tissue, some show hydropic degeneration and many show variations in staining (Fig. 3).

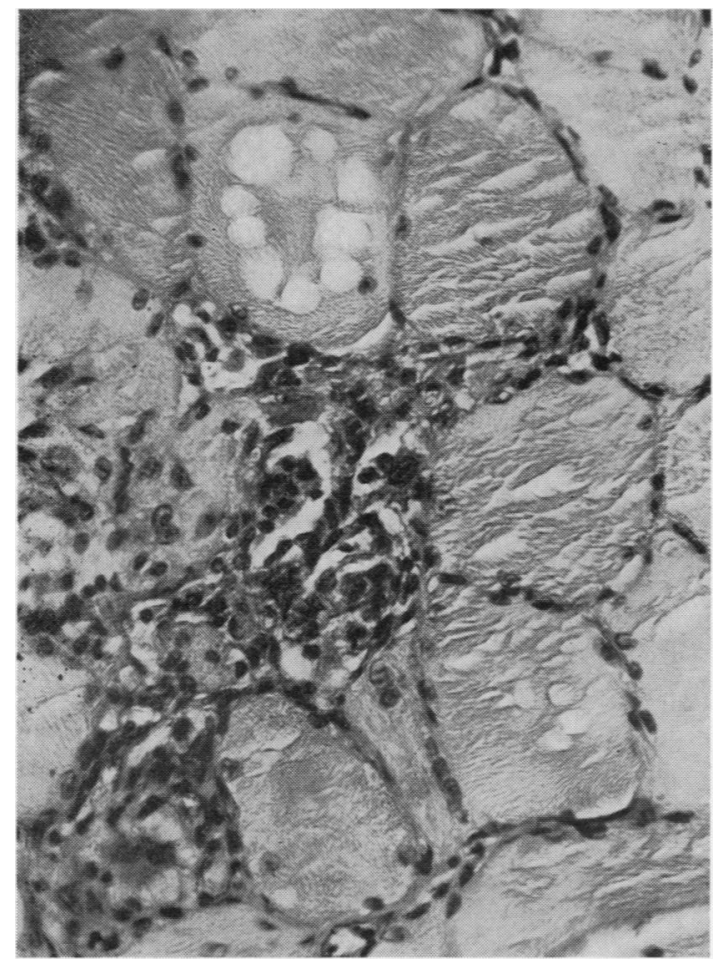

Fig. 3.-- Biopsy of quadriceps muscle, showing interstitial cellular infiltration.

The remains of a medium-sized muscular artery are present. The adventitia shows extensive fibrosis and lymphocytic infiltration with a large number of small periadventitial blood vessels (Fig. 4).

Numerous iron-containing macrophages are also present. The media has been destroyed, but a quantity of

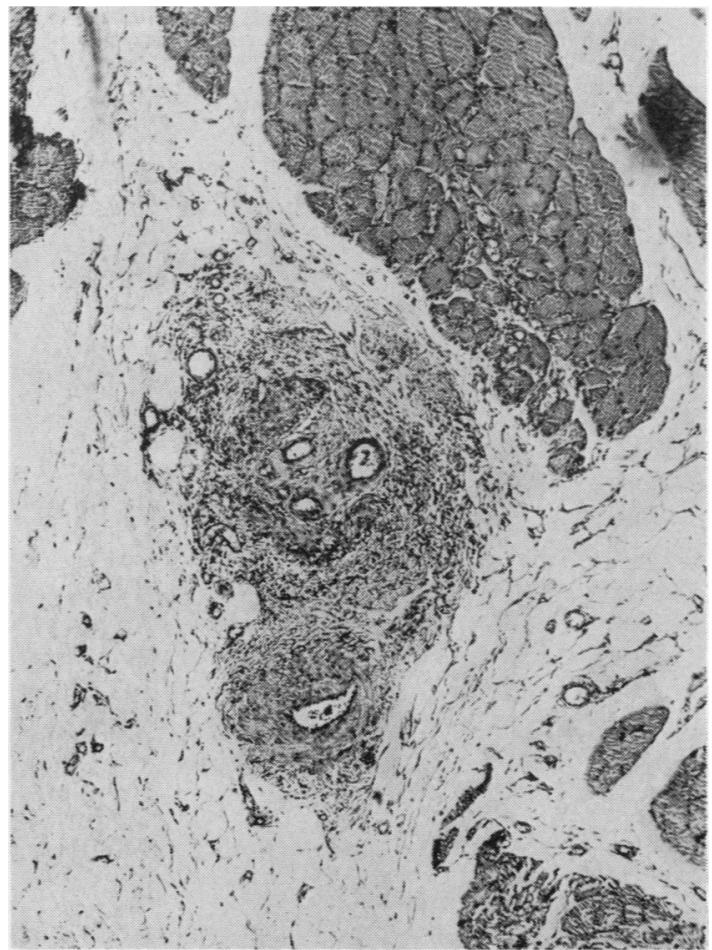

Fig. 4.-Biopsy of quadriceps muscle, showing extensive adventitial fibrosis and lymphocytic infiltration.

eosinophilic fibrinoid material remains. The internal elastic lamina is fragmented. The lumen has been entirely obliterated, apparently by intimal proliferation and a number of new channels lined by endothelium have been formed. No giant cells are seen.

\section{Discussion}

Since it was first clearly recognized 70 years ago by Hutchinson, the clinical spectrum of temporal arteritis has gradually enlarged as the giant-cell reaction or similar histological findings have been identified in large and medium-sized arteries throughout the body, e.g. in the aorta and coronary arteries (Cooke, Cloake, Govan, and Colbeck, 1946), limb arteries (Frangenheim, 1951), mesenteric arteries (Russell, 1959), and intracranial arteries (Crompton, 1959). Fortunately for the physician, the involvement of the branches of the external carotid which occurs during the course of the illness usually enables the diagnosis to be made and confirmed by biopsy.

An illness of elderly patients, consisting of generalized muscle pain and wasting with fever and constitutional disturbance, was clearly defined by Kersley (1951) and by Bagratuni (1953), and was 
named anarthritic rheumatism. The view that these cases represented a distinct clinical entity has been confirmed by later writers (Barber, 1957; Gordon, 1960), but the aetiology remains obscure. A markedly raised erythrocyte sedimentation rate due to hyperfibrinogenaemia, hypo-albuminaemia with excess of globulin, and hypochromic or normochromic anaemia are common features, and the differential sheep-cell agglutination test is sometimes positive. Muscle biopsies have been performed in a few cases but have proved negative or unhelpful (Kersley, 1951; Bagratuni, 1953); it is not clear whether or not a muscular artery has previously been examined.

Since cranial arteritis is known to follow or to be accompanied by similar muscular symptoms, it has been considered that the two diseases might be related, but because of the absence of headache, because normal pulsation is present in temporal arteries, and because biopsy of the affected muscle has been negative, this has been thought unlikely. Recently, however, cases have been reported in which a transition from cranial arteritis to anarthritic rheumatism has been observed (Russell, 1959; Paulley and Hughes, 1960), although histological proof of arteritis has been lacking. The present case is important in that arteritis was shown to exist in the temporal artery and a year later the small muscular arteries showed a similar chronic inflammation at a time when the clinical picture was typical of anarthritic rheumatism.

Histologically, the muscular arteritis showed necrotic and inflammatory changes, particularly in the adventitia, with fibrinoid degeneration of the muscle layer. In the quadriceps biopsy the inflammatory reaction was less intense and there was evidence of considerable adventitial fibrosis. Giant cells were only occasionally seen, and the general histological appearance in the muscular arteries resembled that of polyarteritis nodosa more closely than that of giant-cell arteritis. This may be a consequence of the size of artery involved and does not necessarily indicate a different disease process.

Clinically and electromyographically, the condition described here resembles the proximal muscle wasting which frequently follows triamcinolone therapy (Dubois, 1958; Williams, 1959), but may also occur after corticosteroids (Harman, 1959). Muscle biopsy in such cases shows atrophy without interstitial infiltration, and it seems unlikely that corticosteroids were any more than a contributing factor in the present case. A definitive diagnosis by muscle biopsy is desirable, since steroid myopathy requires a change or reduction in steroid dosage and arteritis requires an increase. The possibility that corticosteroids may cause arteritis? has been suggested in connexion with the arteriai: lesions of rheumatoid disease (Kemper, Baggenstoss and Slocumb, 1957), and cannot be excluded in the present case. However, in two similar cases. previously reported, no corticosteroid treatment hasf been given (Russell, 1959).

It seems unlikely that reduction in blood supplyes alone could account for all the muscular symptomsand signs. The muscle pain was not strictly related to exercise and was frequently worse at rest. Thछ proximal distribution of painful muscles and the degree of wasting were unlike anything seen in the common types of occlusive arterial disease affectingi the limbs. The simple test of exercising the limb after arterial occlusion with a cuff, in order to see whether pain was reproduced, was unfortunately not carried out. There was no evidence from clinicag examination, electromyography, or muscle biopsy, of any peripheral nerve or motor neurone involve $\_$ ment, and biochemical analysis of plasma failed to show any abnormality.

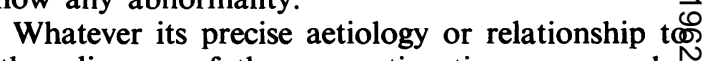
other diseases of the connective tissues, muscular polyarteritis should be considered in the differentiab diagnosis of chronic myalgia and weakness in elderly subjects, and particular inquiry should be made for a history of temporal headache.

\section{Summary}

A patient is described in whom a typical attack of temporal arteritis was followed by a chronie condition of muscle pain and wasting. This was associated with inflammatory changes in the muscuō lar arteries and by some histological evidence oţ myositis. Muscular arteritis is suggested as a cause of chronic myalgic symptoms in elderly patients.

My thanks are due to Dr. Violet Macdermot whø performed the muscle biopsy.

\section{REFERENCES}

Bagratuni, L. (1953). Ann. rheum. Dis., 12, 98.

Barber, H. Stuart (1957). Ibid., 16, 230.

Cooke, W. T., Cloake, P. C. P., Govan, A. D. T., and Colbeck, J. C. (1946). Quart. J. Med., n.s. 15, 47פ Crompton, M. R. (1959). Brain, 82, 377.

Dubois, E. L. (1958). J. Amer. med. Ass., 167, 1590. Frangenheim, H. (1951). Zbl. allg. Path. path. Anat. 88,81 .

Gordon, I. (1960). Quart. J. Med., 29, 473.

Harman, J. B. (1959). Lancet, 1, 887.

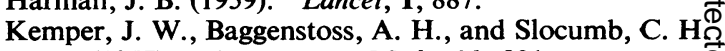
(1957). Ann. intern. Med., 46, 831.

Kersley, G. D. (1951). "Proc. II Congr. Europ. Reum. 1951, Barcelona", p. 388. 
Paulley, J. W., and Hughes, J. P. (1960). Brit. med. J., $2,1562$.

Russell, R. W. Ross (1959). Quart. J. Med., n.s. 28, 471. Williams, R. S. (1959). Lancet, 1, 698.

\section{Atteinte musculaire dans l'artérite á cellules géantes}

RÉSUMÉ

On décrit un malade chez qui une attaque typique d'artérite temporale fut suivie d'un état chronique de douleur et d'atrophie musculaire. Cela fut associé à des lésions inflammatoires dans les artères musculaires et des signes histologiques de myosite. On pense que l'artérite musculaire est une des causes des symptômes myalgiques chroniques chez des malades âgés.

\section{Afectación muscular en la arteritis de células gigantes}

Sumario

Se describe un enfermo en el que un típico ataque de arteritis temporal fué seguido por un estado crónico de dolor y atrofía muscular. Esto fué asociado con lesiones inflamatorias en las arterias musculares y con cierta evidencia histológica de miositis. Se sugiere la arteritis muscular como una de las causas de los síntomas miálgicos crónicos en pacientes de edad avanzada. 